\section{Cohort study for monitoring cardiovascular risk factors in children using a primary health care service: methods and initial results}

\author{
Estudo de coorte para vigilância dos fatores \\ de risco cardiovascular em crianças na \\ atenção básica de saúde: métodos \\ e primeiros resultados
}

Sueli Rosa Gama 1

Marilia Sá Carvalho 1

Leticia de Oliveira Cardoso 1

Celia Regina Moutinho de Miranda Chaves 2

Elyne Montenegro Engstrom 1

\section{Introduction}

An awareness of the presence of cardiovascular disease risk factors since childhood is essential to guide health promotion policies. The aim of this paper is to present, together with the main results, a methodological proposal to estimate both incidence and prevalence of these factors over time and their associated socio-demographic aspects in a population attending a primary health care unit, within Brazilian Unified National Health System. An open cohort design was adopted, starting in 2004 with a sample of 356 children aged between 5 and 9. In the second wave, in 2008, 126 children were enrolled and 205 were reevaluated. Socioeconomic variables, food intake, physical activity, anthropometric measures (weight, height and waist size), lipidogram and glycemia were collected. Results indicate a high prevalence of dyslipidemia, and an increase of excess weight and sedentary activity between both surveys. Some 55\% of children were found to have lower values of HDL-cholesterol. The methodological proposal was considered adequate for the monitoring of cardiovascular disease predictors in poor urban populations.

Dyslipidemias; Child; Risk Factors
The growing prevalence of cardiovascular diseases and diabetes worldwide, including in developing countries, is the result of an increase of potentially modifiable risk factors. Among them, inadequate food intake, sedentary activity, obesity and dyslipidemia are found to be present in populations at increasingly earlier ages $1,2,3,4$. In infancy and adolescence, the presence of these risk factors increases the probability of cardiovascular diseases later in life 5,6. The most recurrent pathogenesis for cardiovascular diseases is, undoubtedly, atherosclerosis, with its onset and progressive development from infancy, which is likely to stay hidden for many years and is therefore undervalued in this age group 5,7,8,9.

The mechanisms involved in the onset of the atherosclerotic disease are extremely complex and involve an interaction between genetic and socio-environmental factors. Lipoproteins play an important role in the etiology of atherosclerotic disease and high values of low density lipoprotein (LDL-c) increase the risk of this deterioration. Recent studies have shown that low levels of high density lipoprotein (HDL-c) favor the formation of atherosclerotic plaques 6,10 .

In Brazil, cross-sectional studies in a child population have identified a high prevalence of isolated or conjoined cardiovascular disease risk factors, during this important life cycle period $11,12,13,14,15$. Thus, cardiovascular disease preven- 
tion policies and actions, and health promotion among children, particularly within the primary health system, must be based on three key points: (i) risk factors for cardiovascular disease development in adults begin at infancy 5,9,15,16,17; (ii) behaviors related to these factors are socially determined 18; (iii) they impact most acutely on the most disadvantaged social groups 19,20, since the family plays a key role in replicating these behaviours and children are more susceptible to influences on their behavior. Given these considerations, the family health care strategy represents a significant opportunity for changing these issues.

In this context, in 2004 the health center at the Sergio Arouca National School of Public Health (ENSP)/Oswaldo Cruz Foundation (Fiocruz) implemented a survey of adult cardiovascular disease risk factors in pre-pubertal children ${ }^{15}$. The health center operates in the neighborhood of Manguinhos in the city of Rio, where it has been present for more than 100 years. Manguinhos is classified as one of the five areas of the city with the lowest Human Development Index (Brazilian Institute of Geography and Statistics. Data from the demographic census of 1991 and 2001. http://www.pnud.org.br, accessed on 10/Feb/2010) 21. The family health care strategy has been implemented in the area since 2001, and in 2008, there were eight teams with 66 professionals operating among a population of over 50,000 inhabitants (http://www. pnud.org.br, accessed on 10/Feb/2010).

The high prevalence of dyslipidemia (64\%) and excess weight (23\%) 15 led to the development of a cohort study of this population. This survey has thereby become the baseline for an open follow-up study for monitoring cardiovascular diseases risk factors. Our proposal is to observe and analyze its evolution among children from this community. The same children will be reevaluated and new children of the same age group will be incorporated, within a triennial period, in order to estimate the prevalence and incidence of those risk factors. In this paper, we will present in detail the methodology of the proposed study and the preliminary results of the baseline and first follow-up.

\section{Material and methods}

On the basis of the prevalence of obesity and related outcomes from the initial study 22, a cohort study was implemented in the same group with an initial follow-up in 2008. The open cohort allows for the assessment of the prevalence of risk factors studied for each segment and also their incidence in the population enrolled. Thus, at every moment, we have a panel of the indicators evaluated and, as such, outcomes are always presented by taking into account both this panel and the cohort itself.

The research ethics committee of ENSP/ Fiocruz approved each stage of the project and an informed consent term was signed by the children's parents at each moment of contact.

\section{Baseline}

The survey implemented in 2004, which represents the baseline of this cohort study, included pre-pubescent children between the ages of five and nine attended at the health center. From a total of 2,760 children aged between 5 and 9 who used the health service annually, a sample size of 356 children was estimated, considering a $5 \%$ error for the estimation of obesity prevalence 23 . Children were invited to participate during the daily admission for all types of care for this age group at the health center. Eligibility criteria were age, pre-pubescent as auto-evaluated using Tanner criteria for sexual maturity (with help from the investigator) and those not attending specifically for nutritional consultancy 24. A questionnaire with data relating to socioeconomic, demographic and health-associated behaviors was used. Evaluation of food intake was based on a 24 hour record and a qualitative food frequency questionnaire, adapted from Sichieri 25. Sedentary activities were evaluated with direct questions estimating the number of hours watching TV and playing electronic games, using a cut-off point of four hours/day 26. Physical activities were evaluated in minutes, based on time spent in formal physical education at school or elsewhere. Anthropometric measurements were weight and height measured according to Lohman 27. Biochemical blood tests were carried out after a 12 hour fast, using standard techniques for spectrofometry (total cholesterol, fractions and glycemia) and Friedewald/Fredrickson's formula (LDL-c) ${ }^{28}$. Whenever the return was delayed by more then four weeks after the first contact, telephone calls were used to stimulate participation. At this stage 231 children (65\%) participated. Details are presented elsewhere 22 .

\section{Follow-up}

The first follow-up was carried out in 2008 following the main outcomes - dyslipidemia and excess weight - at baseline 15 . New children were incorporated keeping the same age proportions as the baseline, in order to maintain the representativeness of the younger group, assessing 
120 children from five through seven years old. The enrollment followed the same strategy as the initial study. The participation of the primary care agents was important to stimulate the return of the baseline children. The questionnaire, simplified to make data collection easier, was applied to the adult responsible for the child at the health centre. However, a new socioeconomic covariate was collected: access to the Bolsa-Família (Family Welfare Program), a national program that consists of a direct cash transfer to extremely poor families, with a monthly income of up to $\mathrm{R} \$ 140$ per person (or less then US\$2/day).

Biochemical and anthropometric procedures were maintained. Waist size 29 was added measured using nonelastic tape according to the World Health Organization (WHO) 30 reference measurement procedures. Furthermore another instrument was included 31 focussed on food risk markers for cardiovascular diseases in children. Blood pressure was not repeated in the follow-up due to the very small prevalence detected in the baseline 22 .

Indicators

Nutritional diagnosis was carried out based on the body mass index (BMI) for age, gender and height and this classification was used at the following cut-points: percentile of low weight $<3$; percentile of eutrophy $\geq 3$ and $<85$; percentile of overweight $\geq 85$ and $<97$; percentile of obesity 97. For height, the height/age index was used, with a cut-off point at percentile $<3$ for low height and the percentile $\geq 3$ for normal height (World Health Organization. http://www.who. int/growthref/who2007_bmi_for_age/en/index. html, accessed on 20/Jul/2008). For waist size, the cut-off point was the 95 percentile for age and gender 26. Lipidogram normality values 32 were: total cholesterol $<150 \mathrm{mg} / \mathrm{dL}, \mathrm{HDL}-\mathrm{c} \geq 45 \mathrm{mg} / \mathrm{dl}$, LDL-c $<100 \mathrm{mg} / \mathrm{dL}$, triglyceride $<100 \mathrm{mg} / \mathrm{dL}$ and $<99 \mathrm{mg} / \mathrm{dL}$ for glucose.

\section{Dataset and statistical analysis}

Statistical analysis has always considered two aspects: the panel and the cohort. For the prevalence analysis in the panel, a level of statistical significance adopted a p-value of $5 \%$. For the incidence analysis, all follow-up indicators were comparatively evaluated in relation to the first wave. Pre-pubertal and pubertal children, whenever indicated, were separately assessed.

Version 1 of the Epi-data program (Epidata Association, Odense, Denmark) was used for data entry, with restrictions and automatic va- lidity check. Data analysis was performed using free software R (The R Foundation for Statistical Computing, Vienna, Austria; http://www.r-proj ect.org). The Nutwin program (Escola Paulista de Medicina, Universidade Federal de São Paulo, São Paulo, Brazil) was used to estimate macroand micronutrients.

\section{Results}

The flow chart in Figure 1 shows the process of child enrollment, blood exams and the followup of children following each contact. The cohort began in 2004 with 356 children, from which 231 (65\%) completed the exams. The initial 2008 strategy was to enroll all children who had blood sample in the 2004 study for the follow-up. The persistent contact by family health care agents, use of a family telephone line and visits to the neighborhood school were some of the strategies employed in order to obtain a $88.7 \%$ (of 231) adherence rate for children in this first follow-up. Even so, not all children returned. Reasons, when given, included: only seven families decided not to participate anymore, and 16 had moved from the area. The majority just did not come in spite of at least three contacts, by phone, at school and at home. However 34 children without biochemistry in the first exam, informed of the follow-up descided to participate spontaneoulsy. Therefore the 2008 cohort comprised 482 participants, with 205 children at both times and 150 children effectively undergoing a blood exam on both cohort waves (Figure 1).

Table 1 presents the main sociodemographic characteristics of each study wave. A slightly higher proportion of male children (54\%) was observed in the first study and a smaller proportion in 2008. Out of the total, $45 \%$ in 2004 and 51.4\% in 2008 lived in dwellings with over four people. A telephone was found in $78 \%$ of the group, with no important variation in both moments, making it easier to contact families.

In the second wave, $40 \%$ of children were from families that were part of the Bolsa-Família. In relation to 2004 , there was found to be an increase (from $18.5 \%$ to $29 \%$ ) in the number of families with a per capita income of more than $\mathrm{R} \$ 200 /$ month and a decrease in families with a per capita income below $\mathrm{R} \$ 100$ between 2004 and 2008. As for the mother's level of schooling, in the second wave, there was a small trend towards higher education levels.

Table 2 describes the prevalence of cardiovascular disease risk factors. Obesity, watching TV and playing electronic games presented an increasing frequency. It is worth highlighting the 


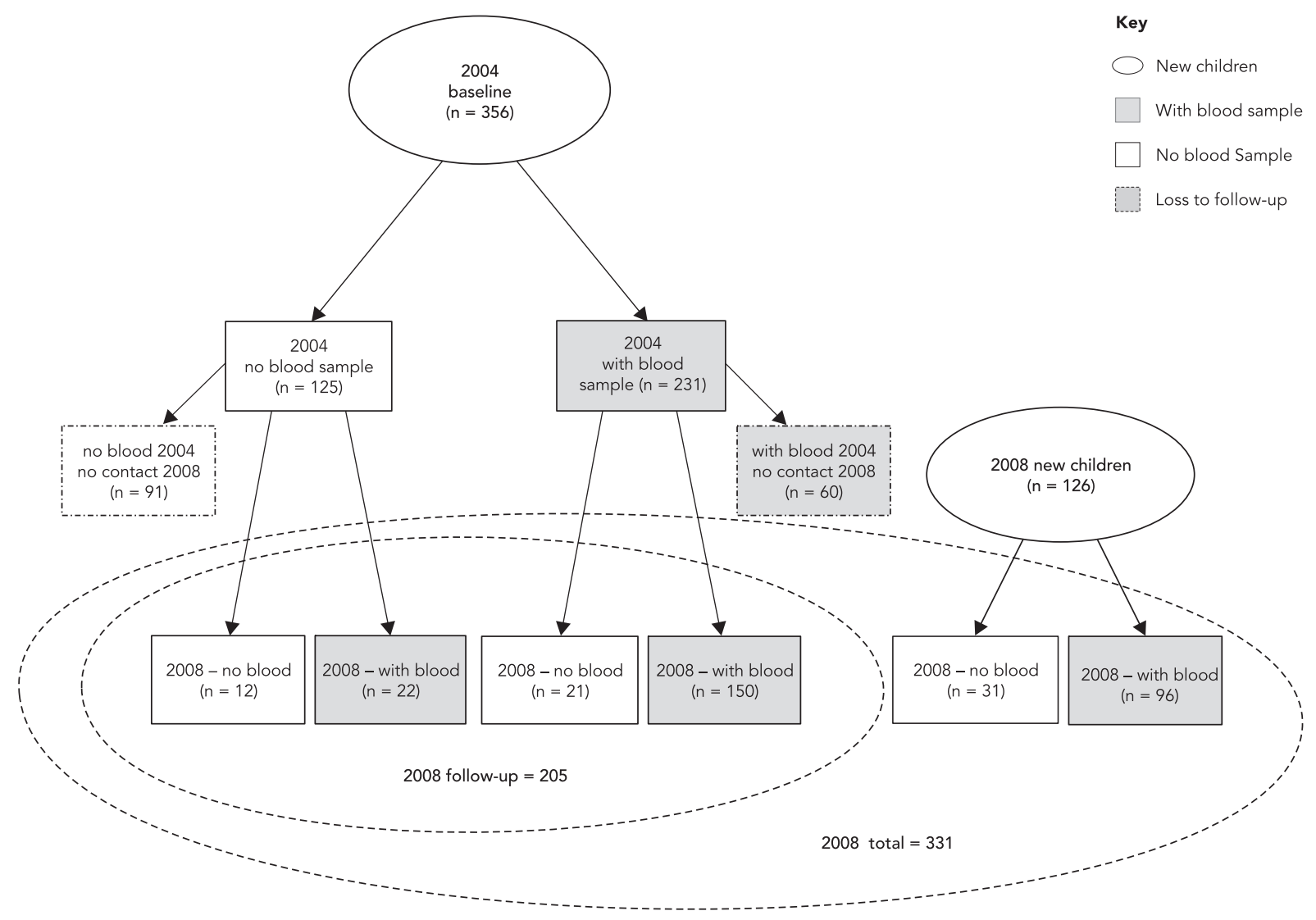

growth of overweight/obesity: in 2004 these categories represented $23 \%$ of children; it rose to $25 \%$ in pre-pubertal children and to $38.9 \%$ in pubertal children in 2008. Sedentary activities, including watching television for more than four hours per day, increased among the pre-pubertal from $37 \%$ to $43.8 \%$ and applied to $59 \%$ of pubertal interviewees. Waist circumference had a prevalence of $24.5 \%$ above percentile 95 for age and gender in pre-pubertal children and nearly $38 \%$ among pubertal children.

In 2004 the frequency of adequate levels of total cholesterol and LDL-c was larger than in 2008. However, HDL-c has shown an inverse trend, with more children presenting low levels in 2008. Concerning triglyceride and glycemia, the results were practically the same in both measures (Table 3).

In Figure 2, cohort follow-up results, meaning children with two complete blood exams, make it possible to analyze the incidence of lipidogram and glycemia deviations. The results indicate an improvement in the cholesterol and triglyceride profile in the LDL-c fraction. The HDL-c fraction changed with a significant worsening. Of 101 children that presented normal values in the first study, 46 remained in this condition and 55 presented non normal values in 2008 , in other words, there was a change of status towards inadequacy in $55 \%$ of the children.

\section{Discussion}

Because dyslipidemia is a silent risk factor for cardivascular diseases not often identified in childhood, the observation of such behavior over time, along with other more visible factors, could help in the formulation and implementation of successful health promotion strategies focused 
Distribution of children according to socioeconomic and demographic variables in 2004 and 2008.

\begin{tabular}{|c|c|c|c|c|}
\hline \multirow[t]{2}{*}{ Variables * } & \multicolumn{2}{|c|}{$2004(n=356)$} & \multicolumn{2}{|c|}{$2008(n=331)$} \\
\hline & n & $\%$ & $\mathrm{n}$ & $\%$ \\
\hline \multicolumn{5}{|l|}{ Sex } \\
\hline Male & 193 & 54.3 & 159 & 48.0 \\
\hline Female & 163 & 45.7 & 172 & 52.0 \\
\hline \multicolumn{5}{|l|}{ Age (years) } \\
\hline $5-9$ & 356 & 100.0 & 170 & 51.5 \\
\hline $10-14$ & - & - & 161 & 48.5 \\
\hline \multicolumn{5}{|l|}{ Puberty } \\
\hline Pre-pubertal & 356 & 100.0 & 222 & 67.7 \\
\hline Pubertal & - & - & 106 & 32 \\
\hline \multicolumn{5}{|l|}{ Color/race } \\
\hline White & 110 & 30.9 & 116 & 35.3 \\
\hline Non white & 246 & 69.1 & 213 & 64.7 \\
\hline \multicolumn{5}{|c|}{ Family income per capita (R\$) } \\
\hline$<100$ & 158 & 44.4 & 115 & 35.9 \\
\hline $101-200$ & 132 & 37.1 & 112 & 35.0 \\
\hline$>200$ & 66 & 18.5 & 93 & 29.1 \\
\hline \multicolumn{5}{|l|}{ Mother's schooling } \\
\hline No schooling & 10 & 2.8 & 13 & 4.0 \\
\hline Incomplete primary & 126 & 35.8 & 97 & 30.0 \\
\hline Complete primary & 148 & 42.0 & 149 & 46.2 \\
\hline Secondary and higher & 68 & 19.4 & 64 & 19.8 \\
\hline \multicolumn{5}{|c|}{ Number of residents in household } \\
\hline 4 or fewer & 173 & 48.6 & 181 & 54.7 \\
\hline 5 or more & 183 & 51.4 & 150 & 45.3 \\
\hline \multicolumn{5}{|c|}{ Telephone (landline or mobile) } \\
\hline Yes & 253 & 71.1 & 257 & 77.6 \\
\hline
\end{tabular}

* Differences in the totals due to non-response for some variables.

on preventing those diseases in later life. In this context, this study design - an open cohort - established in a primary health care unit, a component part of the SUS (Unified National Health System), will allow the observation of the incidence of cardiovascular disease risk factors, here treated as outcomes.

The increase of the BMI and sedentarism is noteworthy here, especially in the pubertal group. Within those four years, the lipidogram measures had improved. It is important to note that nutritional education interventions (individual and group activities) were carried out, targeting changes in the eating behavior of children detected with excess weight or dyslipidemia. In addition, a few methodological issues involving routine data collection are under development, in order to evaluate the health center interventions.
The comparison between 2004 and 2008 indicates changes in social variables: the number of people living in the same household decreased and the number of families with a per capita income of more than $\mathrm{R} \$ 200$ increased over this time period. It is possible that the federal government Family Welfare Program, that assists low income families has influenced this social mobilization, as suggested by the fact that $40 \%$ of the sample received benefits under this program in 2008 33,34. Such acknowledgment reinforces the appropriateness of the study design with its panel component.

One of the limitations of the study was the changes in the questionnaire between both interviews. Although intended to evaluate the appropriateness of a more simplified instrument and thereby facilitate data collection, there was also found to be a loss of information in very 
Prevalence of cardiovascular diseases risk factors in the children in 2004 and 2008, according to the puberty stage in 2008.

\begin{tabular}{|c|c|c|c|c|c|c|}
\hline \multirow[t]{3}{*}{ Variables } & \multirow{2}{*}{\multicolumn{2}{|c|}{$\begin{array}{l}2004 \\
\text { Pre-pubertal }(n=356)\end{array}$}} & \multicolumn{4}{|c|}{2008} \\
\hline & & & \multicolumn{2}{|c|}{ Pre-pubertal $(n=222)$} & \multicolumn{2}{|c|}{ Pubertal $(n=106)$} \\
\hline & $\mathrm{n}$ & $\%$ & $\mathrm{n}$ & $\%$ & $\mathrm{n}$ & $\%$ \\
\hline \multicolumn{7}{|l|}{$\mathrm{BMI}$ * } \\
\hline Low weight & 7 & 2.0 & 12 & 5.4 & 2 & 1.9 \\
\hline Adequate & 267 & 75.0 & 155 & 69.8 & 66 & 62.3 \\
\hline Overweight & 44 & 12.3 & 22 & 10.0 & 23 & 21.7 \\
\hline Obesity & 38 & 10.7 & 33 & 14.8 & 15 & 14.1 \\
\hline Total ** & 356 & 100.0 & 222 & 100.0 & 106 & 100.0 \\
\hline \multicolumn{7}{|c|}{ Waist classification } \\
\hline$<\mathrm{P} 95$ & NA & NA & 167 & 75.5 & 66 & 62.3 \\
\hline$\geq$ P95 & NA & NA & 54 & 24.5 & 40 & 37.7 \\
\hline Total ** & NA & NA & 221 & 100 & 106 & 100.0 \\
\hline \multicolumn{7}{|c|}{ Sedentary activities (minutes) } \\
\hline $120^{\prime}$ & 126 & 35.5 & 26 & 24.8 & 8 & 12.1 \\
\hline $120-240^{\prime}$ & 95 & 26.8 & 33 & 31.4 & 19 & 28.8 \\
\hline $240-360^{\prime}$ & 78 & 21.9 & 27 & 25.7 & 17 & 25.8 \\
\hline$>360^{\prime}$ & 56 & 15.8 & 19 & 18.1 & 22 & 33.3 \\
\hline Total ** & 355 & 100.0 & 105 & 100.0 & 66 & 100.0 \\
\hline \multicolumn{7}{|c|}{ Physical activities (minutes) } \\
\hline$\leq 60$ & 136 & 38.2 & 30 & 18.5 & 17 & 21.5 \\
\hline$>60$ & 220 & 61.8 & 167 & 81.5 & 62 & 78.5 \\
\hline Total ** & 356 & 100.0 & 197 & 100.0 & 79 & 100.0 \\
\hline
\end{tabular}

BMI: body mass index; NA: not available.

*World Health Organization, http://www.who.int/growthref/who2007_bmi_for_age/en/index.html (accessed on 20/Jul/2008);

** Differences in the totals due to non-response in some variables.

sensitive areas, such as family structure, physical activity and socioeconomic status. Therefore the questionnaire will be reviewed for the next follow-up.

The participation of family health care agents who live in the area, and who are responsible for guiding the local population in their use of the health center, was an important foctor in ensuring adequate levels of child enrollment and adherence, taking into consideration the life conditions of the population being studied 35 . This area remains in a state of constant public insecurity, which, at certain moments, prevents the free displacement of users. In addition, situations of great fragility - unemployment, illiteracy, lack of family structure - are common in the area and make the conscious participation and valorization of health care difficult. At the study baseline, the families of the children that did not return to collect the blood sample had less paternal presence, more illiteracy and lower income 22 . In other words, the access impairment is still high among children in a situation of family and social frailty. In this way, methods for increasing the participation of those children in the study must be pursued, in order to achieve a more precise and unbiased picture of the prevalence and incidence of cardiovascular disease risk factors. On the other hand, structural changes related to a large urban renewal program generated population displacements within the area. Even when it is possible to locate the families, this movement cannot be anticipated and occurs in several directions, even back to the risk areas from where people have been removed 21,36 . One of the setbacks against adherence is the need for a twelve hour fasting period prior to taking the blood sample. A recent publication 37 suggests that there is no need for fasting for the lipidogram to cardiovascular risk assessment. This procedure, if adopted as a research protocol, would increase adherence to the exam.

Avoiding bias introduced by selective losses to follow-up is the main challenge of any cohort 
Table 3

Prevalence of normal and altered biochemistry in 2004 and 2008, according to the stage of puberty in 2008.

\begin{tabular}{|c|c|c|c|c|c|c|}
\hline \multirow[t]{3}{*}{ Variables } & \multirow{2}{*}{\multicolumn{2}{|c|}{$\begin{array}{l}2004 \\
\text { Pre-pubertal }(n=231)\end{array}$}} & \multicolumn{4}{|c|}{2008} \\
\hline & & & \multicolumn{2}{|c|}{ Pre-pubertal $(n=179 *)$} & \multicolumn{2}{|c|}{ Pubertal $(n=86)$} \\
\hline & $\mathrm{n}$ & $\%$ & $\mathrm{n}$ & $\%$ & $n$ & $\%$ \\
\hline \multicolumn{7}{|c|}{ Total cholesterol } \\
\hline Normal & 73 & 31.6 & 117 & 65.4 & 53 & 61.6 \\
\hline Altered & 158 & 68.4 & 62 & 34.6 & 33 & 38.4 \\
\hline \multicolumn{7}{|l|}{$\mathrm{LDL}$ ** } \\
\hline Normal & 115 & 49.8 & 117 & 65.7 & 68 & 79.1 \\
\hline Altered & 116 & 50.2 & 61 & 34.3 & 18 & 20.9 \\
\hline \multicolumn{7}{|l|}{ HDL } \\
\hline Normal & 150 & 64.9 & 58 & 32.4 & 27 & 31.4 \\
\hline Altered & 81 & 35.1 & 121 & 67.6 & 59 & 68.6 \\
\hline \multicolumn{7}{|c|}{ Triglyceride ** } \\
\hline Normal & 199 & 86.1 & 152 & 85.4 & 69 & 80.2 \\
\hline Altered & 32 & 13.9 & 26 & 14.6 & 17 & 19.8 \\
\hline \multicolumn{7}{|l|}{ Glycemia } \\
\hline Normal & 225 & 97.4 & 175 & 98.3 & 81 & 94.2 \\
\hline altered & 6 & 2.6 & 3 & 1.7 & 5 & 5.8 \\
\hline
\end{tabular}

* Two children were not classified;

** One child without analysis for these fractions.

Figure 2

Evolution of biochemistry for children evaluated both in 2004 and 2008.




study. A strategy based on voluntary adherence would improve the follow-up, but would make it impossible to infer the population's risk factor prevalence, the other main aim of this work. The random sampling strategy for including new subjects allows a reasonable estimate of prevalence. Our choice was towards a "quick and dirty" design, certainly not optimal, but feasible in the study environment: a primary health care localized in a very deprived area 38 . Besides, although failing to come back to collect blood in the baseline, some children came to the follow-up, suggesting that the best strategy is to call all children to every follow-up contact, as adherence may change. In spite of all "real world" limitations, losses were relatively small as shown in Figure 1.

Waist size is a cardiovascular disease risk marker in adults. The Bogalusa Heart Study 39 with children and adolescents has found a direct association between waist size and high levels of triglycerides, LDL-c and insulin; and an indirect association with low HDL-c levels, independent of race, gender, BMI and height. Thus, waist circumference measurement can be employed as a clinical parameter connected to infant juvenile obesity, replacing laboratory exams that may not be easily done, such as insulinemia. Notwithstanding, the literature still lacks a universal standard for the characterization of waist obesity in children and adolescents 40 , not an easy task, considering that the cut-off points for risk may vary according to ethnicity and gender 41 , thus justifying its inclusion in this study.

Diabetes was not detected in any children using just fast glycemia. Certainly, other methods would be more sensitive in the age group, such as the oral glucose tolerance test 42 and to hyperinsulinemic-euglycemic clamp ${ }^{44}$. However, the feasibility of these exams in the context of the study and in primary health care conditions is small. The absence of the exam and non-fasting might increase adherence.

One of the main methodological challenges of this study is the follow-up of subjects undergoing major physical, psychic and social transformations - puberty. The lipidogram evolution itself during this stage points to assessment problems in the analysis. Studies show that throughout puberty in subjects of both sexes with a normal BMI, total cholesterol and all fractions except the HDL-c decrease. However HDL-c decreases in males, but remains the same in female adolescents $44,45,46$.

As new follow-ups are carried out, statistical methods appropriate for repeated measures 47 will be implemented. However, the adolescent group, initially, will be analyzed separately by gender, even with the consequent loss of power. The possibility of expansion of the sample in this group will be considered.

This open cohort model is innovative in the context of primary health care and family health care. We showed it is feasible and its longitudinal characteristic is appropriate for the family health care model, as it allowed for the identification of changes not only in the incidence but also in the prevalence of the major predictors of the cardiovascular diseases, a major problem of the most disadvantaged populations in the developing world.

\section{Resumo}

Conhecer a presença de fatores de risco para as doenças cardiovasculares desde a infância é essencial para orientar políticas de promoção da saúde. O objetivo deste artigo é apresentar, junto com os principais resultados, uma proposta metodólogica para estimar incidência e prevalência, ao longo do tempo, desses fatores e fatores sociodemográficos associados em população assistida em unidade básica, integrante do Sistema Único de Saúde do Brasil. Adotou-se o desenho de uma coorte aberta, iniciada em 2004, com amostra de 356 crianças de 5-9 anos. Na segunda onda, em 2008, 126 crianças aderiram, e 205 foram reavaliadas. Coletou- se dados socioeconômicos, alimentares, de atividade física, antropométricos (peso/altura/perímetro da cintura), lipidograma e glicemia. Os resultados apontam alta prevalência de dislipidemia, aumento do excesso de peso e de tempo sedentário entre ondas. Em 55\% das crianças, os valores de HDL-colesterol foram mais baixos. A proposta metodológica apresentada mostrou-se adequada para a vigilância dos preditores das doenças cardiovasculares em populações urbanas carentes.

Dislipidemias; Criança; Fatores de Risco 


\section{Contributors}

All the authors participated in the article conception, data analysis and interpretation, article write-up, critical revision and approval of the final version for publication. In addition, S. R. Gama was responsible for data collection.

\section{Acknowledgements}

We thank Else Bartholdy Gribel, head of the health center of the Sergio Arouca National School of Public Health, Oswaldo Cruz Foundation, for her support; all workers at the health center, particualrly the community health agents; Dora Chor and Maria de Jesus Mendes da Fonseca for their valuable comments on earlier versions. This study was funded by a grant from the Rio de Janeiro State Research Foundation. M. S. C. also received funding from the Barziliam Council for Scientific and Technological Development.

\section{References}

1. Monteiro CA, Mondini L, Souza ALM, Popkin BM. Da desnutrição para a obesidade: a transição nutricional no Brasil. In: Monteiro CA, organizador. Velhos e novos males da saúde no Brasil: a evolução do país e de suas doenças. 2a Ed. São Paulo: Editora Hucitec/Núcleo de Pesquisas Epidemiológicas em Nutrição e Saúde, Universidade de São Paulo; 1995. p. 248-55.

2. World Health Organization. Obesity. Preventing and managing the global epidemic. Geneva: World Health Organization; 1998.

3. Freedman DS, William HD, Srinivasan SR, Berenson GS. The relation of overweight to cardiovascular risk factors among children and adolescents: the Bogalusa Heart Study. Pediatrics 1999; 103(6Pt1):1175-82.

4. Instituto Brasileiro de Geografia e Estatística. Pesquisa Nacional de Saúde do Escolar. Rio de Janeiro: Ministério da Saúde/Ministério do Planejamento Orçamento e Gestão; 2009.
5. Gerber ZRS, Zielinsky P. Fatores de risco de aterosclerose na infância: um estudo epidemiológico. Arq Bras Cardiol 1997; 69:231-6.

6. Magnussen CG, Venn A, Thomson R, Juonala M, Srinivasan SR, Viikari JS, et al .The association of pediatric low- and high-density lipoprotein cholesterol dyslipidemia classifications and change in dyslipidemia status with carotid intima-media thickness in adulthood: evidence from the cardiovascular risk in young Finns study, the Bogalusa heart study and the CDAH (childhood determinants of adult health) study. J Am Coll Cardiol 2009; 53:860-9.

7. Lópes-Simon L, Oya M, Lasuncion MA, Riestra P, Benavente M, Oya I, et al. Genetic determinants of plasma HDL-cholesterol levels in prepuberal children. Clin Chim Acta 2009; 403:203-6.

8. Berenson GS, Srinivasan SR, Nicklas TA. Atherosclerosis: a nutritional disease of childhood. Am J Cardiol 1998; 82:22-9. 
9. Williams CL, Hayman LL, Daniels SR, Robinson TN, Steinberger J, Paridon S, et al. Cardiovascular health in childhood: a statement for health professionals from the Committee on Atherosclerosis, Hypertension and Obesity in the Young (AHOY) of the Council on Cardiovascular Disease in the Young, American Heart Association. Circulation 2002; 106:143-60.

10. Shah PK. High-density lipoprotein mimetics: focus on synthetic high-density lipoprotein. Am J Cardiol 2007; 100(11A):S62-7.

11. Levy-Costa RB, Sichieri R, Pontes NS, Monteiro CA. Disponibilidade domiciliar de alimentos no Brasil: distribuição e evolução (1974-2003). Rev Saúde Pública 2005; 39:530-40.

12. Ribeiro RQ, Lotufo PA, Lamounier JA, Oliveira RG, Soares JF, Botter DA. Fatores adicionais de risco cardiovascular associados ao excesso de peso em crianças e adolescentes: o estudo do coração de Belo Horizonte. Arq Bras Cardiol 2006; 86:408-18.

13. Rabelllo LM. Fatores de risco para doença aterosclerótica na adolescência. J Pediatr (Rio J.) 2001; 77 Suppl 2:S153-64.

14. Sarni RS, Souza FISS, Schoeps DO, Catherino P, Oliveira MCCP, Pessoti CFX, et al. Relação da cintura abdominal com a condição nutricional, perfil lipídico e pressão arterial em pré-escolares de baixo estrato socioeconômico. Arq Bras Cardiol 2006; 87:153-8.

15. Gama SR, Carvalho MS, Chaves CRMM. Prevalência em crianças de fatores de risco para as doenças cardiovasculares. Cad Saúde Pública 2007; 23:2239-45.

16. Dutra CL, Araújo CL, Bertoldice AD. Prevalência de sobrepeso em adolescentes: um estudo de base populacional em uma cidade no Sul do Brasil. Cad Saúde Publica 2006; 22:151-62.

17. Castro IR, Cardoso LO, Engstrom EM, Levy RB. Surveillance of risk factors for non-communicable diseases among adolescents: the experience in Rio de Janeiro, Brazil. Cad Saúde Pública 2008; 24:2279-88.

18. Chor D, Faerstein E. Um enfoque epidemiológico da promoção da saúde: as idéias de Geoffrey Rose. Cad Saúde Pública 2000; 16:241-4.

19. Dietz WH. Childhood weight affects adult morbidity and mortality. J Nutr 1998; 128(2 Suppl): 411S-4S.

20. Seligman HK, Laraia BA, Kushel MB. Food insecurity is associated with chronic disease among low-income NHANES participants. J Nutr 2010; 140:304-10.

21. Peçanha CT, Costa RGR, Fernandes TM. Memória e conflitos sociais no espaço urbano. Manguinhos. Rio de Janeiro, 2007. http://www.encontro2008. rj.anpuh.org/../1214230187_arquiv (accessed on 10/Feb/2010).

22. Gama SR. Detecção de fatores de risco para doenças cardiovasculares em crianças de 5 a 9 anos de idade atendidas em uma unidade básica de saúde [Dissertação de Mestrado]. Rio de Janeiro: Instituto Fernandes Figueira, Fundação Oswaldo Cruz; 2005

23. Kish L. Survey sampling. New York: John Wiley \& Sons; 1965.
24. Tanner JM, Whitehouse RH. Clinical longitudinal standards for height, weight, height velocity, weight velocity, and stages of puberty. Arch Dis Child 1976; 51:170-9.

25. Sichieri R. Epidemiologia da obesidade. Rio de Janeiro: EdUerj; 1998.

26. Viner RM, Cole TJ. Television viewing in early childhood predicts adult body mass index. J Pediatr 2005; 147:429-35.

27. Lohmnan TG, Roche AF, Martorell R. Anthropometrics standartization reference manual. Champaign: Human Kinetics Books; 1998.

28. Friedewald WT, Levy RI, Fredrickson DS. Estimation of the concentration of low-density lipoprotein in plasma without use of the preparative ultracentrifuge. Clin Chem 1972; 18:499-502.

29. McCarthy HD, Jarrent KV, Crawley HF. The development of waist circumference percentiles in British children aged 5.0-16.9 y. Eur J Clin Nutr 2001; 55:902-7.

30. World Health Organization. Steps surveillance last updated: 12 december 2008. Measuring waist circumference. htt://www.who.int/entity/chp/steps/ Part3_Section3.pdf (accessed on 12/Sep/2009).

31. Chiara VL, Sichieri R. Consumo alimentar em adolescentes: questionário simplificado para avaliação de risco cardiovascular. Arq Bras Cardiol 2001; 77:332-6.

32. Sociedade Brasileira de Cardiologia. I diretriz de prevenção da aterosclerose na infância e na adolescência. Arq Bras Cardiol 2005; 85 Suppl 6:3-36.

33. Nery M. Desigualdade, estabilidade social e bem estar social. Ensaios Econômicos 2006; (637):1-39.

34. Soares SD. Distribuição de renda no Brasil de 1976 a 2004 com enfase no período de 2001 a 2004. Brasília: Instituto de Pesquisa Econômica e Aplicada; 2006.

35. Mackenbach JP, Looman CW, der Meer JB. Differences in the misreporting of chronic conditions, by level of education: the effect on inequalities in prevalence rates. Am J Public Health 1996; 86: 706-11.

36. Torres HG. Segregação residencial e políticas públicas: São Paulo na década de 1990. Rev Bras Ciênc Soc 2004; 19:41-55.

37. Danesh J, Di Angelantonio E, Sarwar N, Perry P, Kaptoge S, Ray KK, et al. Emerging risk factors collaboration major lipids, apolipoproteins, and risk of vascular disease. JAMA 2009; 302:1993-2000.

38. Streiner DL, Norman GR. PDQ epidemiology. 3rd Ed. Shelton: People's Medical Publishing House; 2009.

39. Freedman DS, Serdula MK, Srinivasan SR, Berenson GS. Relation of circumferences and skinfold thicknesses to lipid and insulin concentrations in children and adolescents: the Bogalusa Heart Study. Am J Clin Nutr 1999; 69:308-17.

40. Barlow SE, Dietz WH. Obesity evaluation and treatment. Expert Committee recommendations. The Maternal and Child Health Bureau, Health Resources and Services Administration and the Department of Health and Human Services. Pediatrics 1998; 102:E29. 
41. Klein DJ, Aronson-Friedman L, Harlan WR, Barton BA, Schreiber GB, Cohen RM, et al. Obesity and development of insulin resistance and impaired fasting glucose in black and white adolescent girls: a longitudinal study. Diabetes Care 2004; 27 : 378-83.

42. Sinha R, Fisch G, Teague B, Tamborlane WV, Banyas B, Allen K, et al. Prevalence of impaired glucose tolerance among children and adolescents with marked obesity. N Engl J Med 2002; 346:802-10.

43. Mathews DR, Rudenski AS, Naylor BA, Treacher DF, Turner RC. Homeostasis model assessment: insulin resistance and beta-cell function from fasting plasma glucose and insulin concentrations in man. Diabetologia 1985; 28:412-9.

44. Berenson GS, Srinivasan SR, Cresanta JL, Foster TA, Webber LS. Dynamic changes of serum lipoproteins in children during adolescence and sexual maturation. Am J Epidemiol 1981; 113:157-70.
45. Hoffman RP, Vicini P, Sivitz WI, Cobelli C. Pubertal adolescent male-female differences in insulin sensivity and glucose effectiveness determined by the one compartment minimal model. Pediatr Res 2000; 48:384-8.

46. Magnussen CG, Raitakari OT, Thomson R, Juonala M, Patel DA, Viikari JS, et al. Utility of currently recommended pediatric dyslipidemia classifications in predicting dyslipidemia in adulthood. Evidence from the childhood determinants of adult health $(\mathrm{CDAH})$ study, cardiovascular risk in young finns study and Bogalusa Heart Study. Circulation 2008; 117:32-42.

47. Diggle PJ, Heagerty P, Liang KY, Zeger SL. Analysis of longitudinal data. 2nd Ed. Oxford: Oxford University Press; 2002.

Submitted on 19/Jun/2010

Final version resubmitted on 15/Oct/2010 Approved on 26/Oct/2010 